Problem Total Activity Impairment. ${ }^{2} P$ values from 2 -sided $t$ test for scale variables and Fisher exact test for categorical variables; statistical comparison between $\mathrm{nr}$ axSpA and AS; ${ }^{*} \mathrm{p}<0.05,{ }^{* *} \mathrm{p}<0.001$

Conclusions: Clinical features and disease burden were generally similar between nr-axSpA and AS pts in the Chinese PROOF subpopulation. AS pts were more frequently men, had higher inflammatory burden (CRP and ASDAS$\mathrm{CRP}$ ), more functional impairment, and were more frequently treated with TNF inhibitors.

Acknowledgements: AbbVie funded the study and analysis, and approved the abstract for submission. Medical writing support was provided by Wendy Gloffke, PhD, of Complete Publication Solutions, LLC (North Wales, PA, USA), and was funded by AbbVie.

Disclosure of Interest: F. Huang: None declared, C. Bao: None declared, Y. Fang Consultant for: AbbVie and Pfizer, Speakers bureau: AbbVie and Pfizer, L. Wu Consultant for: AbbVie, Speakers bureau: AbbVie, L. Jiang: None declared, D. He: None declared, J. Xu: None declared, F. Zhang Consultant for: AbbVie, Speakers bureau: AbbVie, X. Zhang: None declared, L. Bi: None declared, M. Hojnik Employee of: AbbVie, D. Poddubnyy Grant/research support from: AbbVie, Janssen, MSD, Novartis, Pfizer, Consultant for: AbbVie, BMS, Boehringer, MSD, Novartis, Pfizer, and UCB, Speakers bureau: AbbVie, BMS, Janssen, MSD, Novartis, Pfizer, Roche, and UCB

DOI: 10.1136/annrheumdis-2018-eular.6925

\section{AB0860 ACUTE PHASE REACTANT CHANGE IN ANKYLOSING SPONDYLITIS PATIENTS}

F. Demirer Aydemir ${ }^{1}$, G. Kenarr ${ }^{1}$, B. Zengin ${ }^{1}$, H. Yarkan Tugsal ${ }^{1}$, S. Capar ${ }^{2}$, M. Birlik ${ }^{1}$, F. Onen ${ }^{1}$, N. Akkoc ${ }^{3}$, G. Can ${ }^{1} .{ }^{1}$ Rheumatology; ${ }^{2}$ Department of Statistics., Dokuz Eylul Universty; ${ }^{3}$ Rheumatology, Private Doctor, Izmir, Turkey

Background: The aim of this study is to investigate the levels of acute phase reactants (APRs) in patients with ankylosing spondylitis (AS) at the time of diagnosis and during follow-up. We also evaluated the associations between APR levels and disease activity.

Methods: The study included 948 patients with AS who were followed-up at Dokuz Eylul University School of Medicine Rheumatology outpatient clinic. The patients' erythrocyte sedimentation rate (ESR) and C-reactive protein (CRP) levels across all visits were retrospectively reviewed through the Turkbio registry and the hospital's database. Disease activity and follow-up parameters as BASDAI, ASDAS, BASFI and BASMI were taken from Turkbio visit charts. The correlation between APR and follow-up parameters were evaluated with Spearman correlation coefficient analysis.

Results: There were 948 AS patients (69\% male, mean age 46,6 412,1 years) who fulfilled the 1984 modified New York criteria. At first visit, high levels of CRP and ESR were observed in 626 (68.5\%) and 578 (64.6\%) patients respectively. During follow-up $84.6 \%$ of patients had high CRP and $69.5 \%$ patients had high ESR at any visit (figure 1). However in $10 \%$ of AS patients APRs did not increase at any visits.

There was good correlation between ESR and CRP $(r=0.666, p<0.001)$. A better correlation was observed at first visit between CRP and BASDAI $(r=0.81, p=0.23)$ or ASDAS $(r=0.468, \mathrm{p}<0.001)$ compared to ESR and BASDAI $(r=0.111, \mathrm{p}=0.02)$ or ASDAS $(r=0.334, p<0.001)$ (table 2). Compared to BASDAl, ASDAS with either ESR $(\mathrm{p}<0.001)$ or CRP (very high disease activity $p<0.001$, inactive disease$p=0.001$ ) had better performance in evaluating the activity of the patient in inactive and very high levels of severe disease (table 2).

Abstract AB0860 - Table 1. Demographic and clinical features

\begin{tabular}{lc}
\hline Age; Mean \pm SD (yrs) & $46,6 \pm 12,1$ \\
\hline Age at onset of illness; Mean \pm SD (yrs) & $27,3 \pm 10,5$ \\
Age of diagnosis; Mean \pm SD (yrs) & $34,5 \pm 12,0$ \\
Females/Males sex, $\mathbf{n}(\%)$ & $293(\% 30,9) / 655(\% 69,1)$ \\
HLAB27 Pozitive/Negative/Unknown & $237(\% 25) / 100(\% 10,5) / 611(\% 64,5)$ \\
\hline
\end{tabular}

Abstract AB0860 - Table 2. Correlation between first visit ESR/CRP and disease activity parameters

\begin{tabular}{lcccc}
\hline & \multicolumn{2}{c}{ ESR } & \multicolumn{2}{c}{ CRP } \\
\cline { 2 - 6 } & $\mathbf{r}$ & $\mathbf{p}$ & $\mathbf{r}$ & $\mathbf{p}$ \\
\hline BASDAI & 0111 & $\mathbf{0 , 0 2}$ & $\mathbf{0 , 8 1}$ & 0023 \\
BASMI & 0123 & 0003 & 0205 & $\mathbf{0 , 0 0}$ \\
BASFI & 0219 & $\mathbf{0 , 0 0}$ & 0224 & $\mathbf{0 , 0 0}$ \\
ASDAS & 0334 & $\mathbf{0 , 0 0}$ & 0468 & $\mathbf{0 , 0 0}$ \\
\hline
\end{tabular}

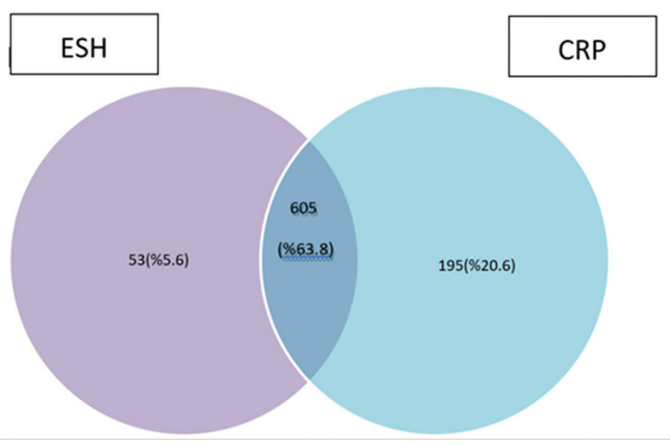

Abstract AB0860 - Figure 1

Abstract AB0860 - Figure 1. Ven diagram of patients that elevation only ESR/ CRP or with both elevation together at any visit

Conclusions: In over $80 \%$ patients with AS had elevated levels of CRP, the most frequently used laboratory parameter, during follow-up. CRP is well correlated with ESR, and disease activity parameters as BASDAI, ASDAS, BASFI and BASMI. Compared to BASDAI; ASDAS had better agreement between activity and APRs. Interestingly, in $10 \%$ of AS patients APRs did never increase in followup.

Disclosure of Interest: None declared

DOI: 10.1136/annrheumdis-2018-eular.6227

\section{AB0861 HEALTH STATUS IN PATIENTS WITH AXIAL SPONDYLOARTHRITIS (AXSPA) AS DETERMINED BY THE ASSESSMENT OF SPONDYLOARTHRITIS INTERNATIONAL SOCIETY HEALTH INDEX (ASAS-HI)}

R. Burgos-Vargas ${ }^{1}$, G. Alva Medina ${ }^{2,3}$, on behalf of Sacroiliacos, I. Peláez Ballestas ${ }^{4}$, C. Ramos-Remus ${ }^{5}$, M. Saavedra Salinas ${ }^{6}$, F. Enriquez-Sosa ${ }^{7}$, A. Guilaisne ${ }^{8}$, C. PACHECO-TENA ${ }^{9}$, G. REYES-CORDERO ${ }^{10}$, O. MUÑOZMONROY $^{11}$, M. PIZAÑA-SERNA ${ }^{12}$, L. SANDOVAL-GARCIA ${ }^{13}$, B. Mota Mondragón $^{14}$, L. Silveira Torre ${ }^{15}$, N. SANTANA ${ }^{16}$, F. MERAYO ${ }^{17}$

M. MARADIAGA-CECEÑA ${ }^{18} .{ }^{1}$ Rheumatology, Hospital General de Mexico, Mexico, Mexico; ${ }^{2} \mathrm{HGM}, \mathrm{CDMX},-;{ }^{3}$ Rheumatology, UNAM; ${ }^{4}$ Rheumatology, Hospital General de Mexico, CDMX; ${ }^{5}$ UAG, Guadalajara; ${ }^{6}$ Rheumatology, CMN LA RAZA, CDMX, Mexico; ${ }^{7}$ Hospital Regional General, $C D ;{ }^{8}$ Hospital Civil de Guadalajara, Guadalajara, -; ${ }^{9}$ UNIVERSIDAD AUTONOMA DE CHIHUAHUA;

${ }^{10}$ HOSPITAL GENERAL, CHIHUAHUA; ${ }^{11}$ HOSPITAL CENTRAL MILITAR, CDMX; ${ }^{12}$ HOSPITAL BELISARIO DOMINGUEZ, TIUXTLA GUTIERREZ;

${ }^{13}$ HOSPITAL GENERAL DEL ESTADO SONORA, HERMOSILLO;

${ }^{14}$ Rheumatology, HOSPITAL CENTRAL MILITAR; ${ }^{15}$ Rheumatology, Instituto Nacional de Cardiología, CDMX; ${ }^{16}$ HOSPITAL DE ESPECIALIDADES MORELOS, CHIHUAHUA; ${ }^{17}$ INSTITUTO NACIONAL DE LA NUTRICION, CDMX ${ }^{18}$ HOSPITAL GENERAL DE YUCATAN, CULIACAN, MexiCO

Background: The ASAS-HI is a new instrument based in the International Classification of Functioning, Disability and Health to assess the impact of axSpA; ASAS-HI has been validated in Mexican patients

Objectives: To investigate the status of health in Mexican patients with axSpA using the ASAS-HI

Methods: This is multicenter, cross-sectional study of $377 / 423$ patients with axSpA (ASAS criteria) referred by 64 rheumatologists with private or institutional practice across the country in a period of six months. Sociodemographic and clinical data were collected at each site and analysed centrally.

Results: The ASAS imaging arm were fulfilled $87.5 \%$ and the clinical by $61.8 \%$; HLA-B27 was positive in $80.1 \% ; 71.6 \%$ were males; $51.9 \%$ received bDMARDs Mean ages at onset and diagnoses were 25.8 (9.9) and 32.8 (11.7) years; median age was 41.6 (13.7) years. The correlation between ASAS-HI and BASDAI BASFI, and EQ-5D was significant. ASAS-HI mean score was 6.4 (4.2); the cut off was six; values below six meant good health, which corresponded to 203 (53.84\%) patients. Univariate analysis disclosed significant differences between groups in variables that were significant in the regression models (see below) and in health care coverage, enthesitis, joint counting, glucocorticoids, HLA-B27, sacroiliitis, BASMI, and ASDAS. In the multivariate analysis, two models were associated ASAS-HI: 1) sex, education, comorbidities, joint surgery, and physician global assessment; 2) BASDAI, BASFI, and EQ-5D

Conclusions: ASAS-HI cut off of six identified good health in $46.15 \%$ of patients with axSpA. ASAS-HI correlated with other measures of disease activity, functioning, and quality of life. In multivariate analysis, ASAS-HI associated with those measures as we all as with demographic and clinical variables. 